\title{
Teleseismic imaging of alpine crustal underthrusting beneath Niberia
}

\author{
J. Díaz, ${ }^{1}$ J. Gallart, ${ }^{1}$ D. Pedreira, ${ }^{2}$ J. A. Pulgar, ${ }^{2}$ M. Ruiz, ${ }^{1}$ C. López, ${ }^{2}$ \\ and J. M. González-Cortina ${ }^{2}$ \\ Received 6 February 2003; revised 31 March 2003; accepted 30 April 2003; published 4 June 2003.
}

[1] The deep crustal structure of the northern part of Iberia, extensively explored by active seismic methods, has been investigated here by the teleseismic receiver function (RF) technique. Two N-S transects were implemented across the Cantabrian Mountains (CMT) and the western Pyrenees (WPT). The resulting RFs were migrated to obtain depth sections of the lithosphere. These images are fairly consistent with previous seismic sections and velocity-depth modeling. The WPT shows a clear northward-dipping interface, interpreted as the Iberian lower crust underthrusting an European Moho identified at the northern end of the transect. In the CMT a similar pattern can be inferred, although the deep crustal geometry is not well resolved. In this transect, intra-crustal convertors are associated to high-velocity materials of European lower crust imbricated at shallower levels. The new results provide farther evidence on the lateral extent of the Alpine underthrusting of Iberia beneath Europe. INDEX TERMS: 0935 Exploration Geophysics: Seismic methods (3025); 7203 Seismology: Body wave propagation; 7205 Seismology: Continental crust (1242); 8110 Tectonophysics: Continental tectonics-general (0905); 9335 Information Related to Geographic Region: Europe. Citation: Díaz, J., J. Gallart, D. Pedreira, J. A. Pulgar, M. Ruiz, C. López, and J. M. González-Cortina, Teleseismic imaging of alpine crustal underthrusting beneath Niberia, Geophys. Res. Lett., 30(11), 1554, doi:10.1029/2003GL017073, 2003.

\section{Introduction}

[2] Following the ECORS seismic surveys carried out across the Pyrenees in the 80 's, extensive seismic research has been performed since the early 90 's in the northwestern part of the Iberian Peninsula. The ESCIN seismic reflection program provided first crustal images beneath the Cantabrian Mountains $(\mathrm{CM})$ and its associated continental margin. [Pulgar et al., 1996; Alvarez-Marrón et al., 1997]. Complementary onshore-offshore wide-angle measurements, as well as two consecutive networks of refraction profiles using land shots gave accurate velocity-depth sections along N-S and E-W transects [Fernández-Viejo et al., 1998, 2000; Pedreira et al., 2003]. A more recent, independent approach to the deep crustal structure of this area is presented here. Two key areas of structural differentiation have been investigated by instrumenting N-S transects along the Western Pyrenees and the central part

\footnotetext{
${ }^{1}$ Department of Geophysics, Institute of Earth Sciences J. Almera, CSIC, Barcelona, Spain.

${ }^{2}$ Department of Geology, University of Oviedo, Spain.
}

Copyright 2003 by the American Geophysical Union. 0094-8276/03/2003GL017073\$05.00 of the Cantabrian Mountains. Teleseismic events are used to analyze $\mathrm{P}$ to $\mathrm{S}$ conversions at main crustal interfaces by means of the receiver function technique. Hereafter the seismic and seismological results are presented and discussed together. The study area (Figure 1) has been affected by the Variscan and Alpine orogenies separated by a large extensional episode. The northern part of Iberia corresponds to the continental margin of Gondwana involved in the Variscan collision with Laurentia [Matte, 1991]. Later on, Mesozoic extensional episodes are responsible for the opening of the North Atlantic Ocean and Bay of Biscay, the formation of the Armorican and Cantabrian margins and the individualization of Iberia as a subplate with left-lateral strike-slip motions [Srivastava et al., 1990]. In Late Cretaceous (83 Ma), a convergence period started, with a relative displacement towards the NW of Iberia with respect to Eurasia [Rosenbaum et al., 2002]. It resulted in the formation of the Pyrenees in the East and the Cantabrian Mountains in the West, with a limited northward subduction of the Iberian plate [Muñoz, 1992; Gallastegui et al., 2002]. The northern branch of the double-vergent Pyrenean Chain is prolonged along the Cantabrian Margin, while the southern branch propagated through the Mesozoic Basque-Cantabrian Basin to the present-day Cantabrian Mountains, uplifted in Eocene to Miocene times [Alonso et al., 1996].

\section{Wide-Angle Modeling}

[3] Vertical and wide-angle seismic profiling at the Cantabrian Mountains and continental margin provided first evidences on the presence of a crustal root beneath the CM, with a northward subduction of the Iberian plate down to at least $55 \mathrm{~km}$ depth [Fernández-Viejo et al., 1998, 2000]. Results from a network of E-W and N-S refraction profiles from the CM to the Pyrenees and the Iberian Chain show a complex signature of the deep reflections [Pedreira et al., 2003]. Along an E-W transect (Figure 2a), a continuous Alpine crustal root is evidenced from the Cantabrian Mountains to the West-Central Pyrenees. In the thickened area, the top of the Iberian lower crust is defined at $\sim 35 \mathrm{~km}$ depth and the Moho is located at $46-48 \mathrm{~km}$ depth, locally raising to $\sim 27 \mathrm{~km}$ and $\sim 40 \mathrm{~km}$ respectively, beneath the BasqueCantabrian Basin. High velocities at mid-crustal depths are identified discontinuously along the profile, and have been associated to portions of a lower crustal wedge from the European domain indenting the Iberian crust during the Alpine stage of compression. The deep part of the European crust is inferred at a much shallower level, with Moho depths less than $30 \mathrm{~km}$. N-S and WSW-ENE profiles (Figures $2 \mathrm{~b}$ and $2 \mathrm{c}$ ) delineate a thinner and stronger European/Cantabrian Margin crust protruding into a thicker Iberian crust, promoting its northward underthrusting and 


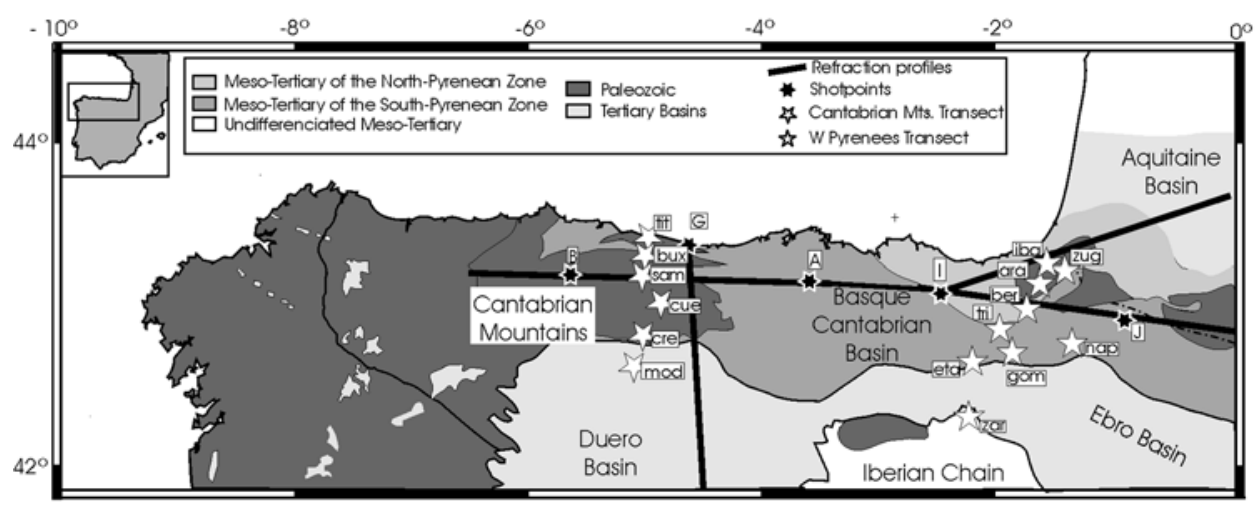

Figure 1. Structural map of the study area. The recording sites for the Cantabrian Mountains and Western Pyrenees transects, and the wide-angle seismic profiles discussed here are shown.

the generation of a double-vergent orogen at upper to midcrustal levels.

\section{Teleseismic Receiver Function Analysis}

[4] Each of the two NS transects has been implemented by deploying 6 Reftek stations equipped with Lennartz geophones with flat response broadened to $5 \mathrm{~s}$ and $20 \mathrm{~s}$. Results after a $9-15$ months operation period are shown here. Teleseismic events with epicentral distances between $35^{\circ}$ and $95^{\circ}$ and clear P arrivals have been retained. Following the method described by Kosarev et al. [1999], the records are rotated to ray components $(\mathrm{L}, \mathrm{Q}, \mathrm{T})$ using back azimuth and incidence angle to minimize energy on the radial and transverse components for the $\mathrm{P}$ arrival. The receiver functions (RF) are then calculated by frequency domain deconvolution of the $\mathrm{L}$ component from the $\mathrm{Q}$ component. In order to get structural information readily comparable to the wide-angle results, we analyse the RF data from two independent procedures. Firstly, the resulting RFs are treated similarly to crustal reflection data, using a simple form of migration [Jones and Phinney, 1998] to obtain images of the lithosphere in depth domain along the recording array (Figures $2 \mathrm{~d}$ and $2 \mathrm{e}$ ). The reference model is divided into $4 \mathrm{~km} \times 4 \mathrm{~km}$ (horizontally) $\times 2 \mathrm{~km}$ (vertically) boxes. The RFs from different stations and events are projected along a profile and are traced back through these boxes. The amplitude contrasts in the final images depict the zones where incoming waves suffer $\mathrm{P}$ to $\mathrm{S}$ conversions. Secondly, 1-D velocity-depth profiles (Figures $2 \mathrm{f}-2 \mathrm{j}$ ) have been derived for each station following a RF inversion procedure [Kind et al., 1995]. However, significant uncertainty is to be related to this procedure [Ammon et al., 1990] and biased interpretations of the crustal structure could easily arise. As additional constraints, we used the information available from wide-angle profiles both to fix the starting model for the inversion and to reject final models with good fitting of the synthetic RF but unrealistic velocity values. The final structural interpretation is therefore based on the joint discussion of the RF depth sections, the inverted 1-D velocity profiles and the previous $2-\mathrm{D}$ velocitydepth models derived from wide-angle data.

\subsection{Cantabrian Mountain Transect}

[5] The southern end of the CMT samples the transition between the Cantabrian Mountains and the Duero Basin, and shows two well-defined convertors, located at 15 and $35 \mathrm{~km}$ depth (Figure 2d). The mid-crustal discontinuity that corresponds to the first one has been evidenced by seismic profiling in other areas of the Iberian Central Massif [Díaz et al., 1993]. The convertor at $35 \mathrm{~km}$ depth is associated to the Moho (Figure 2f), and is coincident with the bottom of the crust interpreted along the N-S profile (Figure 2b). The central part of the transect, near the intersection with the E-W seismic profile, displays a different pattern. The upper convertor is modeled by a thin high-velocity layer (Figure $2 \mathrm{~g}$ ) and can be related to the high-velocity body evidenced in the E-W and N-S seismic profiles (Figures $2 a$ and $2 b$ ). This feature has been interpreted as a slab of European lower crust indenting the Iberian middle crust [Pedreira et al., 2003]. Another convertor remarkably broad, located between 30 and $43 \mathrm{~km}$ depth can be observed (Figure 2d) and related to the lower-crust/upper mantle transition zone. The geometry of this transition is not well constrained with the data available at present, but it may suggest a limited subduction of Iberia northwards. At the northern end of the transect, only one convertor at around $25 \mathrm{~km}$ depth can be identified (Figure 2d). It may correspond to the top of the Cantabrian Margin (European) lower crust according to the velocitydepth modeling [Fernández-Viejo et al., 1998].

\subsection{Western Pyrenees Transect}

[6] The migrated section for the WPT (Figure 2e), shows at its SW end, beneath the Iberian Chain, two main convertors, located at 15 and $38 \mathrm{~km}$ depth, similar to those observed in the southern end of the CMT. The deeper one is associated to the Iberian Moho and can be modeled by a sharp crust-mantle transition (Figure $2 \mathrm{~h}$ ). The central part of the section shows an increasing complexity. The mid-crustal convertor found at $\sim 12 \mathrm{~km}$ depth could be related to the high-velocity materials interpreted in the E-W seismic profile. The most prominent feature in this area is a NEdipping convertor located at $25 \mathrm{~km}$ depth at offsets of 150 $\mathrm{km}$ and reaching $40 \mathrm{~km}$ depth, $70 \mathrm{~km}$ farther to the NE. The E-W and SW-NE seismic profiles [Pedreira et al., 2003] show in this area a prominent reflection on top of the lower crust, clearly more energetic than PmP, whose amplitudes were fitted considering velocities in the Iberian lower crust up to $7.4 \mathrm{~km} / \mathrm{s}$ (Figures $2 \mathrm{a}$ and $2 \mathrm{c}$ ). In the inverted RF model for station BER (Figure 2i), which is approximately located at the crossing point with the E-W profile, this NEdipping convertor appears as a zone of increasing velocities between 30 and $40 \mathrm{~km}$ depth. Therefore, it is interpreted as 

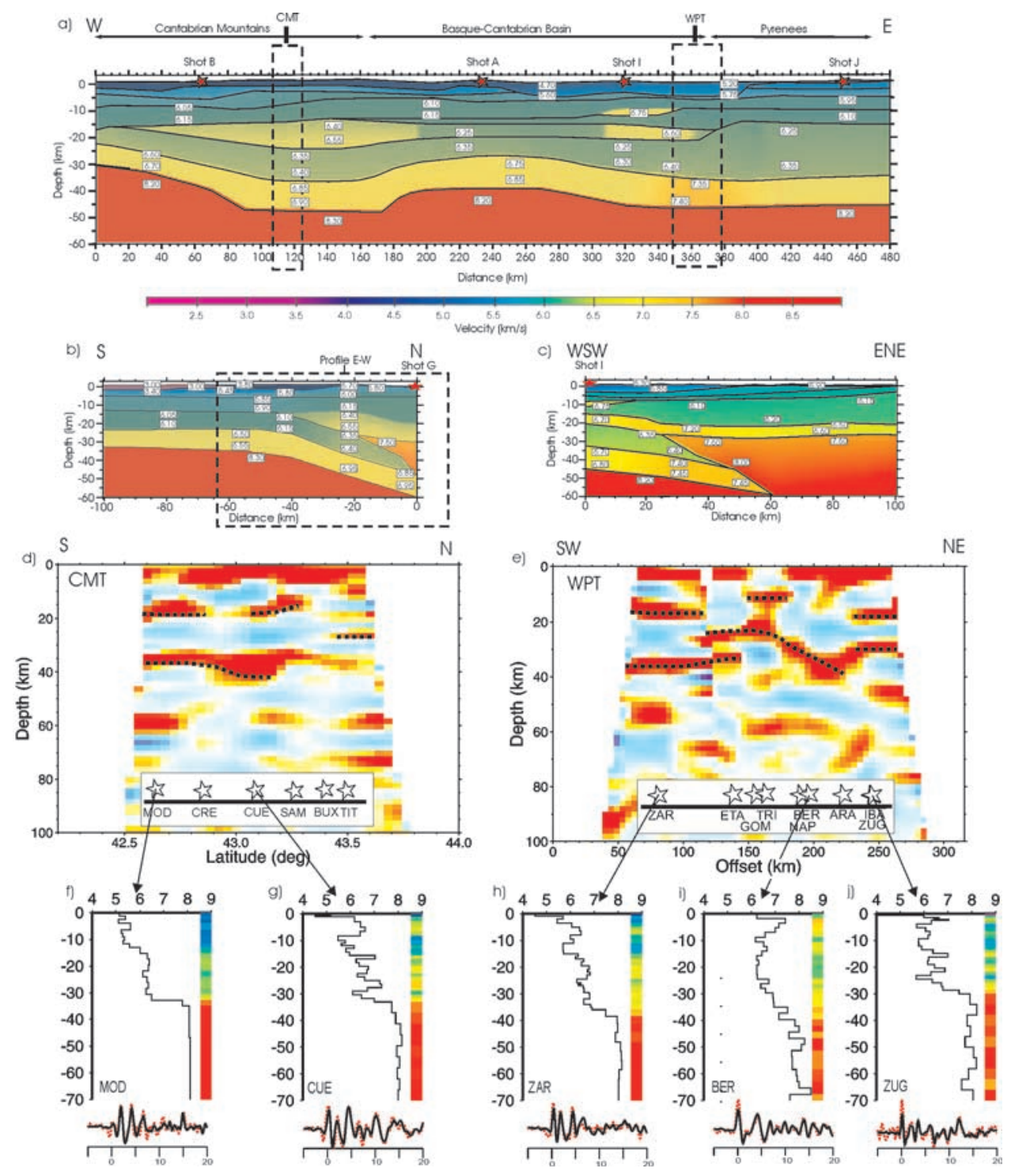

Figure 2. (a), (b) and (c): Velocity-depth models for the E-W, N-S and WSW-ENE wide-angle profiles, obtained from raytracing modeling [modified from Pedreira et al., 2003; Gallastegui et al., 2002]. See Figure 1 for location. Inserts in (a) show the crossing area of the two teleseismic transects. (d) and (e): Pseudo-migrated sections from receiver functions for the Cantabrian Mountains (CMT) and Western Pyrenees (WPT) transects. The interpreted convertors (see text) are marked by discontinous lines. (f), (g), (h), (i) and (j):1-D velocity-depth model and inverted receiver function for stations MOD and CUE along the CMT and stations ZAR, BER and ZUG along the WPT. On the right-hand side of each model, the velocity values are represented by the same color scale used in the wide-angle models.

the signature of the underthrusting Iberian lower crust. Moreover, there is significant energy on the transverse components of the RF on this station, which can also be argued as an evidence for such a dipping convertor. At the northeastern end of the section the convertors depth appear to change significantly. The uppermost one is located at $18 \mathrm{~km}$ depth, and is interpreted as the top of the European lower crust. A second convertor is observed at $28 \mathrm{~km}$ depth and corresponds to the European Moho (Figure 2j).

\section{Discussion}

[7] We started a teleseismic RF analysis in N Iberia, an area extensively investigated in the last years by wide-angle seismic profiling. The corresponding structural images provide a relevant test on resolution power and consistency of both independent methodologies. We may conclude from the RF analysis that, even if the velocity-depth profiles obtained form 1-D inversion significantly lack unicity, RF depth sections provide relevant constraints on crustal geometry, usually consistent with wide-angle models. Minor differences could also be expected due to the predominantly vertical versus predominantly horizontal ray paths involved in the respective methods. Detailed imaging of complex geometries such as a deep crustal indentations seems to be beyond the resolution of the presently available low-density $\mathrm{RF}$ measurements and requires combination of different seismic techniques. RF depth sections have been obtained in two N-S transects across the Cantabrian Mountains and western Pyrenees, using data gathered after several months 
of teleseismic recording. Results are fairly consistent with the wide-angle models that suggest the existence of a crustal thickening and wedging, similar to that already known at the central Pyrenees since the ECORS seismic profile. The southern part of the Cantabrian Mountains transect shows the undisturbed Iberian Variscan crust with the Moho located at $35 \mathrm{~km}$ depth. Farther north, a convertor at midcrustal depths has to be modeled with a high velocity layer, supporting the hypothesis of an indentation of European crust suggested by seismic profiling. In this zone the Iberian crust seems to thick at least to $\sim 43 \mathrm{~km}$ depth, although the deep crustal geometry is not well constrained from the data available at present. The northern end of the transect probably depicts the Cantabrian Margin (European) Moho. At the Western Pyrenees transect, the crustal thickening of the Iberian crust is clearly imaged. In the central part of this transect a dipping convertor is interpreted as the Iberian lower crust underthrusting the European crust. The northernmost stations sample the European Moho at $28 \mathrm{~km}$ depth. The interpretation of migrated RF sections hence supports the indentation between European and Iberian crusts throughout the northern part of the Iberian Peninsula affected by the Alpine compressional tectonics.

[8] Acknowledgments. This work was sponsored by Spanish Research Ministry projects AMB98-1012-C02 and REN2001-1734-C03. M. Ruiz and C. López benefit from a Ph.D. F.P.I. grant. Figures were created using GMT [Wessel and Smith, 1998].

\section{References}

Alonso, J. L., J. A. Pulgar, J. C. García-Ramos, and P. Barba, Tertiary basins and Alpine tectonics in the Cantabrian Mountains (NW Spain), in Tertiary basins of Spain: The Stratigraphic Record of Crustal Kinematics, edited by P. F. Friend and C. J. Dabrio, pp. 214-227, Cambridge University Press, Cambridge, 1996.

Álvarez-Marrón, J., E. Rubio, and M. Torné, Subduction-related structures in the North Iberian Margin, J. Geophys. Res., 102(B10), 22,49722,511, 1997.

Ammon, Ch. J., G. E. Randall, and G. Zandt, On the nonuniqueness of receiver function inversions, J. Geophys. Res., 95(B10), 15,303-15,318, 1990.

Díaz, J., J. Gallart, D. Córdoba, L. Senos, L. Matias, E. Suriñach, A. Hirn, P. Maguire, and ILIHA DSS Group, A Deep Seismic Sounding Investi- gation of Lithospheric Heterogeneity and Anisotropy beneath the Iberian Peninsula, Tectonophysics, 221, 35-51, 1993.

Fernández-Viejo, G., J. Gallart, J. A. Pulgar, J. Gallastegui, J. J. Dañobeitia, and D. Córdoba, Crustal transition between continental and oceanic domains along the North Iberian margin from wide angle seismic and gravity data, Geophys. Res. Lett., 25(23), 4249-4252, 1998.

Fernández-Viejo, G., J. Gallart, J. A. Pulgar, D. Córdoba, and J. J. Dañobeitia, Seismic signature of Variscan and Alpine tectonics in NW Iberia: Crustal structure of the Cantabrian Mountains and Duero basin, J. Geophys. Res., 105(B2), 3001-3018, 2000.

Gallastegui, J., J. A. Pulgar, and J. Gallart, Initiation of an active margin at the North Iberian continent-ocean transition, Tectonics, 17, 2002.

Jones, C. H., and R. A. Phinney, Seismic structure of the lithosphere from teleseismic converted arrivals observed at small arrays in the southern Sierra Nevada and vicinity, California, J. Geophys. Res., 103(B5), 10,065-10,090, 1998

Kind, R., G. L. Kosarev, and N. V. Petersen, Receiver functions at the stations of the German regional seismic network (GRSN), Geophys. J. Int., 121, 191-202, 1995.

Kosarev, G., R. Kind, S. V. Sobolev, X. Yuan, W. Hanka, and S. Oreshin, Seismic evidence for a detached Indian Lithospheric mantle beneath Tibet, Science, 283, 1306-1309, 1999.

Matte, $\mathrm{Ph}$., Accretionary history and crustal evolution of the Variscan belt in Western Europe, Tectonophysics, 196, 309-337, 1991.

Muñoz, J. A., Evolution of a coninental collision belt: ECOR-S Pyrenees crustal balanced cross-section, in Thrust Tectonics, edited by K. McCaly, Chapman \& May, London, 256-246, 1992.

Pedreira, D., J. A. Pulgar, J. Gallart, and J. Diaz, Seismic evidence of Alpine crustal thickening and wedging from the western Pyrenees to the Cantabrian Mountains (north Iberia), J. Geophys. Res., 108(B4), 2204, doi:10.1029/2001JB001667, 2003.

Pulgar, J. A., J. Gallart, G. Fernández-Viejo, A. Pérez-Estaún, J. ÁlvarezMarrón, and ESCIN Group, Seismic image of the Cantabrian Mountains in the western extension of the Pyrenees from integrated ESCIN reflection and refraction data, Tectonophysics, 264, 1-19, 1996.

Rosenbaum, G., G. S. Lister, and C. Duboz, Relative motions of Africa, Iberia and Europe during Alpine orogeny, Tectonophysics, 117-129, 2002.

Srivastava, S. P., H. Schouten, W. R. Roest, K. D. Klitgord, L. C. Kovacs, J. Verhoef, and R. Macnab, Iberian plate kinematics: A jumping boundary between Eurasia and Africa, Nature, 344, 756-759, 1990.

Wessel, P., and W. H. F. Smith, New, improved version of the generic mapping tool released, EOS Trans., $A G U$, 79, 579, 1998.

J. Díaz, J. Gallart, and M. Ruiz, Department of Geophysics, Institute of Earth Sciences J. Almera, CSIC, c/Lluis Sole Sabaris s/n, 08028, Barcelona, Spain. (jdiaz@ija.csic.es)

D. Pedreira, J. A. Pulgar, C. López, and J. M. González-Cortina, Department of Geology, University of Oviedo, c/Arias de Velasco s/n, 33005 Oviedo, Spain. 